\title{
Understanding the Interplay of Institutional Logics and Management Practices in Impact Sourcing
}

DOI:

10.1111/isj. 12254

\section{Document Version}

Accepted author manuscript

Link to publication record in Manchester Research Explorer

\section{Citation for published version (APA):}

Nicholson, B., \& Malik, F. (2019). Understanding the Interplay of Institutional Logics and Management Practices in Impact Sourcing. Information Systems Journal, 30(1), 125-149. https://doi.org/10.1111/isj.12254

\section{Published in:}

Information Systems Journal

\section{Citing this paper}

Please note that where the full-text provided on Manchester Research Explorer is the Author Accepted Manuscript or Proof version this may differ from the final Published version. If citing, it is advised that you check and use the publisher's definitive version.

\section{General rights}

Copyright and moral rights for the publications made accessible in the Research Explorer are retained by the authors and/or other copyright owners and it is a condition of accessing publications that users recognise and abide by the legal requirements associated with these rights.

\section{Takedown policy}

If you believe that this document breaches copyright please refer to the University of Manchester's Takedown Procedures [http://man.ac.uk/04Y6Bo] or contact uml.scholarlycommunications@manchester.ac.uk providing relevant details, so we can investigate your claim.

\section{OPEN ACCESS}




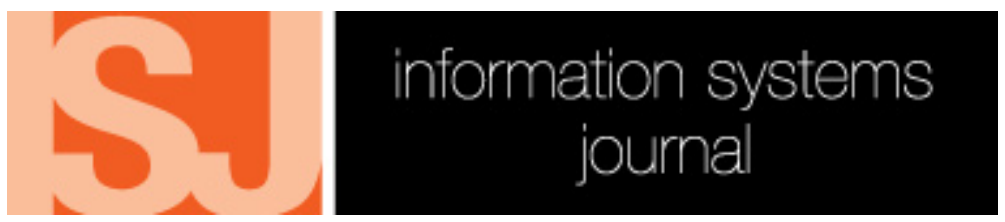

\section{Understanding the Interplay of Institutional Logics and Management Practices in Impact Sourcing}

\begin{tabular}{|c|c|}
\hline Journal: & Information Systems Journal \\
\hline Manuscript ID & ISJ-RE-1372.R6 \\
\hline Wiley - Manuscript type: & Research Article \\
\hline Keywords: & $\begin{array}{l}\text { Impact Sourcing, Institutional Logics, Global IT and Business Process } \\
\text { Outsourcing, Practices, Mechanisms }\end{array}$ \\
\hline Abstract: & $\begin{array}{l}\text { This article draws on the evidence gathered from a research project in } \\
\text { the area of global information technology outsourcing (GITO) involving a } \\
\text { US-based vendor of medical billing and transcription processing with a } \\
\text { subsidiary in a remote area of Pakistan. It contributes to recent debates } \\
\text { on Impact Sourcing-understood as GITO offering social value for } \\
\text { marginalized groups in society. Prior research to date has focused on } \\
\text { "social mission" driven impact sourcing initiatives but examples of } \\
\text { mainstream "market-driven" GITO's engagement in impact sourcing } \\
\text { work are largely absent in the impact sourcing literature. Using } \\
\text { qualitative methods, this study explores the interplay between } \\
\text { institutional logics and management practices of a market-driven GITO } \\
\text { organization engaged in impact sourcing work. The findings identify } \\
\text { family, community and profession logics existing in the subsidiary } \\
\text { location and management practices of the GITO organization responding } \\
\text { to these logics. We abstract the practices into three mechanisms (i.e., } \\
\text { synchronization, bridging, and embedding) and present a process model } \\
\text { that explains the dynamics of institutional logics and institutionally } \\
\text { aligned management practices. This study offers both theoretical and } \\
\text { practical implications to understand the implementation of impact } \\
\text { sourcing initiatives in market-driven GITO scenarios. }\end{array}$ \\
\hline
\end{tabular}

\section{SCHOLARONE ${ }^{\text {M }}$ Manuscripts}




\section{Understanding the Interplay of Institutional Logics and Management Practices in Impact Sourcing}

\section{Fareesa Malik}

NUST Business School

National University of Sciences and Technology

Sector H-12, Islamabad

Pakistan

Email: fareesa.malik@nbs.nust.edu.pk

\section{Brian Nicholson}

Alliance Manchester Business School

The University of Manchester, Booth Street West

Manchester M15 6PB

United Kingdom

Email: brian.nicholson@manchester.ac.uk 


\title{
Understanding the Interplay of Institutional Logics and Management Practices in Impact Sourcing
}

\begin{abstract}
This article draws on the evidence gathered from a research project in the area of global information technology outsourcing (GITO) involving a US-based vendor of medical billing and transcription processing with a subsidiary in a remote area of Pakistan. It contributes to recent debates on Impact Sourcing — understood as GITO offering social value for marginalized groups in society. Prior research to date has focused on "social mission" driven impact sourcing initiatives but examples of mainstream "market-driven" GITO's engagement in impact sourcing work are largely absent in the impact sourcing literature. Using qualitative methods, this study explores the interplay between institutional logics and management practices of a market-driven GITO organization engaged in impact sourcing work. The findings identify family, community and profession logics existing in the subsidiary location and management practices of the GITO organization responding to these logics. We abstract the practices into three mechanisms (i.e., synchronization, bridging, and embedding) and present a process model that explains the dynamics of institutional logics and institutionally aligned management practices. This study offers both theoretical and practical implications to understand the implementation of impact sourcing initiatives in market-driven GITO scenarios.
\end{abstract}

\section{KEYWORDS:}

Impact Sourcing, Institutional Logics, Global IT and Business Process Outsourcing, Mechanisms, Practices 


\section{INTRODUCTION}

Recent research in Information systems (IS) defines impact sourcing as developing marginalized individuals' capabilities to enhance their employment opportunities through outsourcing (Carmel et al., 2014; Khan, et al., 2018). "Impact-sourcing organizations" are outsourcing service providers (i.e., vendors) that contribute to creating social value via the practice of outsourcing. Examples include non-profit and for-profit social enterprises such as CloudFactory - that has a social mission in Kenya and Nepal, Samasource and Digital Data Direct (DDD). Khan et al. (2018) refer to this group of vendors as a new breed of entrepreneurial outsourcing firms that are incepted with a social mission of altruistic intentions (p.538). Prior impact sourcing research has predominately focused on "social mission" initiatives. There is a blind spot in the literature regarding how the mainstream market-driven GITO organizations may contribute to impact sourcing. Understanding the role of this group is important because they vastly outnumber the "social mission" outsourcing enterprises (A.T. Kearney, 2016) and are thus important for wide scale adoption of the practice of impact sourcing. We introduce the term impact sourcing work to denote outsourcing that benefits marginalized groups undertaken as a subset of activity within the confines of a mainstream market-driven GITO.

To make sense of the motivation of mainstream market-driven GITO to engage in impact sourcing we refer to prior research in corporate social responsibility (CSR). Falck \& Heblich (2007) and Porter \& Kramer $(2006,2011)$ amongst others have argued for a 'doing well by doing good' approach to CSR. They argue that for-profit market based corporations that embrace social concerns can create a "dual value" or "win-win" outcome for all stakeholders. Practitioner reports and white papers echo this proposition that impact sourcing offers a "win-win strategy" for all stakeholders, including marketdriven GITO organizations, the marginalized workforce and clients (Accenture, 2012; Avasant, 2012; Monitor, 2011). Conversely, academic research has shown that social value creation of impact sourcing is not a by-product of commercial activities. The studies identify that impact sourcing endeavors are highly challenging-even in altruistic social mission models-and require long-term conscious "frame alignment" efforts 
between the vendor and local community (Sandeep \& Ravishankar 2015a; Sandeep et al., 2013).

This highlights the need for further research into how mainstream market-driven GITO organizations engaged in impact sourcing work respond to the challenges of aligning practices with the local context and achieve sustainable socio-economic returns. Towards this goal, an institutional theory lens has been shown to be of value in making sense of the dynamics of impact sourcing (Khan et al., 2018; Madon \& Ranjini, 2018; Ismail et al. 2017). Of particular relevance to our inquiry is a stream in the management literature focusing on how institutional logics shape operations of organizations (Smets et al., 2015; Greenwood et al., 2010). Institutional logics are defined by Thornton \& Ocasio (2008) as the socially constructed historical patterns of material practices, assumptions, values, beliefs, and rules by which individuals produce and reproduce their material subsistence, organize time and space, and provide meaning to their social reality. We draw on this theory guided by the following research question:

How do market-driven GITO organizations engaged in impact sourcing work respond to the influence of institutional logics?

As an empirical basis to explore this interplay, we conducted an interpretive case study of a New York NASDAQ stock exchange-listed and US-headquartered medical billing GITO organization. This organization (which we call "AlphaCorp" for anonymity) operated its offshore subsidiaries for processing of digitized medical insurance claims in Islamabad and Bagh. In 2005, Bagh district experienced a major earthquake that significantly affected the socio-economic conditions of the community in the subsequent decade.

Our study offers a number of implications for the limited literature and practice of impact sourcing. The study responds to the research calls to study impact sourcing work in market-driven GITO in a novel institutional and geographical context (Carmel et al., 2014; Nicholson, 2015; Sandeep \& Ravishankar, 2015a). It contributes a process framework to understand the interplay of institutional logics with the management practices of market-driven GITO organizations practicing impact sourcing work for 
marginalized groups in the society. The main novel contribution of the study is to draw on social mechanisms as explanatory mid range theory to identify "the process through which an observed outcome was generated" (Avgerou, 2013, p. 409). Thus, this research identifies three mechanisms-Synchronization, Bridging, and Embeddingthrough which the market-driven GITO organizations respond to the institutional logics in the context. This study and the proposed framework can help impact sourcing practitioners, particularly market-driven GITO organizations, to identify the potential institutional challenges that they may face while contributing in impact sourcing work in marginalized communities.

The paper proceeds as follows: in Section 2 and 3 we review the key literature related to institutional logics and impact sourcing followed by the case description. In Section 4 and 5 , we outline our research method followed by the findings and, in Section 6 , the discussion and conclusions.

\section{LITERATURE REVIEW AND CONCEPTUAL FRAMEWORK}

\subsection{Institutional logics}

Institutional logics broadly refers to a social domain's "organizing principles" (Friedland \& Alford, 1991, p. 248), historical patterns of material practices (Thornton \& Ocasio, 2008 ) or "rules of the game" (Thornton \& Ocasio, 2008, p. 112) that are "woven into the fabric of regulatory structures, organizational forms and social norms and specify which issues to consider salient, which ends to pursue, which means to employ, and which standards to use to define success" (Smets et al., 2015, p. 934). Friedland \& Alford (1991) first brought the notion of institutional logics to the attention of institutional theory scholars. Their contribution was to conceptualize society as an inter-institutional system where behavior in a context is theorized with reference to societal sectors ("orders") that represent sets of expectations for social relations and organizational behavior. The key institutional orders were identified as the capitalist market, bureaucratic state, democracy, nuclear family, and Christian religion each with its own distinct logic. The logics of each institutional order-which all have their own distinguishing principles, practices, and norms that both enable and constrain individuals and organizations- 
shape individual and organizational practices (Greenwood et al., 2010; Smets et al., 2012).

A stream in the management literature has built on this insight to specifically theorize the linkages between institutional theory and organizational practices (Suddaby et al., 2013). Furthermore, Smets et al. (2012) and Smets et al. (2015) have operationalized a practice perspective in relation to identifying and analyzing the influence of institutional logics. This approach is illustrated in Smets et al.'s (2015) analysis of the conflicting logics and "balancing" mechanisms in the case of reinsurance trading in Lloyds of London where ethnography reveals the interplay of the shared practical understandings with overarching institutional logics. Practices are defined as organized constellations of actions (Schatzki, 1996, 2006) and patterns of activities that indicate common purpose and understanding of how specific activities should be done (Jarzabkowski \& Spee, 2009). Thus, Smets et al.'s (2015) approach to making sense of the influence of institutional logics on organizations focuses on identifying the practices by which individuals dynamically negotiate institutional complexity in their normal work (Barley, 2008). Our theoretical position in this paper is broadly aligned with Smets' approach of identifying the influence of institutional logics (through inductive data analysis that is explained further in the research method's section) and the practices observed in the workplace that represent the GITO organization's response and interplay with institutional logics.

\subsection{Impact sourcing}

Although relatively nascent, a significant literature on impact sourcing has emerged and Table 1 provides an overall summary. The initial academic studies were focused on groups at "the bottom of the pyramid"1 and assessed impact on socio-economic conditions (Heeks \& Arun, 2010; Madon \& Sharanappa 2013). Carmel et al. (2014) extended the scope of the definition to include individuals and groups marginalized not only by income but also characteristics related to education, race, gender, religion, or disability. In terms of the type of work, a series of reports and white papers emerged

1 The bottom of the pyramid refers to the poor segment of the population that lives under US $\$ 2.50$ per day (Prahalad, 2009). 
from 2011 onwards that initially identified business process outsourcing services as the main vehicle for impact sourcing (Monitor, 2011) but later this was extended to all digitally enabled services such as medical transcription, data entry and software development.

A further distinction in the literature relates to research location. The early studies focused on rural areas in developing countries particularly in India (Heeks \& Arun, 2010; Madon \& Sharanappa, 2013) and the India trend has continued into more recent work (Malik et al., 2016; Sandeep \& Ravishankar, 2015b). However, other scholars have examined impact sourcing targeted at marginalized groups in both rural and urban areas of developed countries, including prisoners, members of aboriginal communities, and military veterans (Babin et al., 2016; Lacity et al., 2012; Lacity et al., 2014).

Overall, the early literature expressed considerable optimism regarding the social value of impact sourcing. A parallel stream of practitioner reports and whitepapers attempted to "sell" the concept by focusing on the "dual value" (Accenture, 2012; Avasant, 2012; Monitor, 2011). Some reports provided social impact measures (Accenture, 2013; William Davidson Institute, 2013) and reported optimistic findings. Although these practitioner reports claim that impact sourcing is viable for mainstream market-driven GITO (Accenture, 2012; Monitor, 2011), there is a paucity of evidence. Prior studies are limited to the "social mission" impact-sourcing organization that are incepted with altruistic intentions applying social enterprise or public private partnership business models (Khan et al., 2018; Madon \& Sharanappa, 2013; Sandeep et al., 2013). The dominant focus of research involves public sector driven initiatives (Ismail et al., 2017, Heeks \& Arun, 2010), development agencies (Malik et al., 2017) and social entrepreneurs (Khan et al., 2018; Madon \& Sharanappa, 2013; Malik et al., 2016). This leaves an under researched area of how market-driven GITO may harness the impact sourcing model. Furthermore, focusing only on "social mission" organizations may divert the impact sourcing practice from its original concept of creating dual social and economic value and presents the possibility of impact sourcing restricted to the practices of the development community rather than mainstream business (Sandeep \& Ravishankar, 2015a). 
Contemporary research has expressed skepticism and critique of the impact sourcing model exploring the challenges and tensions surrounding how the "dual value" focus may be attained. Sandeep \& Ravishankar (2015a) for instance identify tensions emanating from the local community. They conclude that social value creation of impact sourcing is not a by-product of commercial activities but is an outcome of long-term conscious efforts of the impact-sourcing organization (Sandeep \& Ravishankar, 2015b). The authors applied impression management and frame alignment concepts to examine how resistance from local community can be managed by creating a positive image of the impact sourcing ventures. This stream of research has significantly improved our understanding on institutional constraints in the context.

Recent research has demonstrated the value of analysis using institutional logics such as Khan et al. (2018) who introduced a conceptual framework with four dimensions (i.e., primary mission, success criteria, resource mobilization, and innovation approach) anchored across social and commercial institutional logics. Using the framework they analyze a US-based outsourcing social enterprise that focuses on the workforce of military veterans and spouses of military personnel. The study shows the "dual value" in action expressed in social logic for the primary mission and resource mobilization, commercial logic for its success criteria, and both logics for innovation. By contrast, Ismail et al. (2017) apply institutional logics to understand the roots and management of conflicts in impact-sourcing public/private partnerships where powerful commercial interests are shown to overwhelm the social goals. Although not drawing on a logics perspective explicitly, Madon \& Ranjini (2018) highlight the influence of policy and institutional environment on operational activities of impact-sourcing organizations and link them with slow growth of impact sourcing sector. This prior work indicates the different institutional forces at play including policy (Madon \& Ranjini, 2018), community (Sandeep \& Ravishankar, 2015), family, professional and personal logics (Malik et al., 2016) that influence the operations of Impact-sourcing organizations.

Little is known about the particular tensions and management practices associated with achieving "dual value" in impact sourcing involving mainstream GITO established with a primary mission of economic value creation and accountability to 
shareholders. In the words of Sandeep \& Ravishankar (2015a) "further research is required to compare and contrast the community-outcome of the more typical profitoriented ventures" (p. 151).

In summary, we identify an emphasis in the extant literature on "social mission" impact sourcing involving cases of social enterprises, NGOs and state-initiated projects. Trivedi and Stokols (2011) point out that these organizations typically have an emphasis on 'social goals' as opposed to economic gains thus any economic profit is understood as a means to solve a social problem. While prior research has recognized that institutional logics create tensions in the management of impact sourcing (Khan et al., 2018; Madon \& Ranjini, 2018; Sandeep \& Ravishankar, 2015), the mechanisms by which market-driven GITO organizations can respond to different institutional logics while managing the social and commercial orientation are still unexplored.

Table 1. Review of key academic research on impact sourcing

\begin{tabular}{|c|c|c|c|c|}
\hline $\begin{array}{l}\text { Impact } \\
\text { sourcing } \\
\text { literature } \\
\text { focus }\end{array}$ & Authors & $\begin{array}{l}\text { Primary mission of } \\
\text { impact-sourcing } \\
\text { organizations }\end{array}$ & Details & General insights \\
\hline \multirow{3}{*}{ 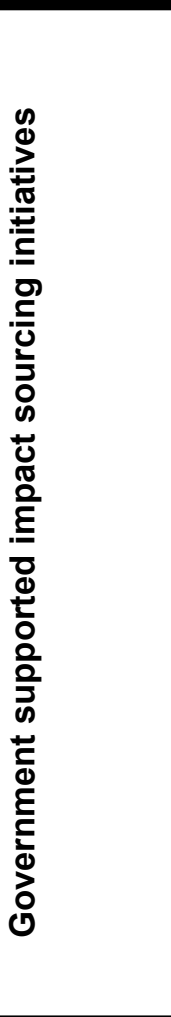 } & $\begin{array}{l}\text { Heeks \& } \\
\text { Arun }(2010)\end{array}$ & $\begin{array}{l}\text { Government } \\
\text { supported enterprises } \\
\text { for poverty reduction }\end{array}$ & $\begin{array}{l}\text { Assesses the impacts on } \\
\text { livelihood } \\
\text { Assets-financial, } \\
\text { human, physical, social, } \\
\text { and political capital. }\end{array}$ & $\begin{array}{l}\text { Business and } \\
\text { development can be } \\
\text { brought together to } \\
\text { reduce poverty. }\end{array}$ \\
\hline & $\begin{array}{l}\text { Lacity et al. } \\
(2014)\end{array}$ & $\begin{array}{l}\text { For-profit government } \\
\text { owned impact } \\
\text { sourcing initiative to } \\
\text { provide employment } \\
\text { opportunities to the } \\
\text { US prisoners }\end{array}$ & $\begin{array}{l}\text { Assesses impact on } \\
\text { prisoners. }\end{array}$ & $\begin{array}{l}\text { Main benefits for } \\
\text { inmates are good } \\
\text { financial } \\
\text { compensation, work- } \\
\text { habit development, } \\
\text { productive occupation } \\
\text { of time, development } \\
\text { of business skills, and } \\
\text { the elevation of self- } \\
\text { efficacy and status. }\end{array}$ \\
\hline & $\begin{array}{l}\text { Ismail et al. } \\
(2017)\end{array}$ & $\begin{array}{l}\text { Government- } \\
\text { supported } \\
\text { public/private } \\
\text { partnership }\end{array}$ & $\begin{array}{l}\text { One partner used a } \\
\text { competitive approach to } \\
\text { conflict management and } \\
\text { the outcome was } \\
\text { domination of private } \\
\text { logic over public logic. } \\
\text { Commercial objectives } \\
\text { sidelined the welfare } \\
\text { goals of impact sourcing. }\end{array}$ & $\begin{array}{l}\text { Institutional logics help } \\
\text { explain the outcome of } \\
\text { development-oriented } \\
\text { IT partnerships with } \\
\text { hybrid goals. The } \\
\text { framework of conflict } \\
\text { management } \\
\text { strategies helps } \\
\text { explain the practice of } \\
\text { institutional logics. }\end{array}$ \\
\hline
\end{tabular}




\begin{tabular}{|c|c|c|c|c|}
\hline \multirow{5}{*}{ 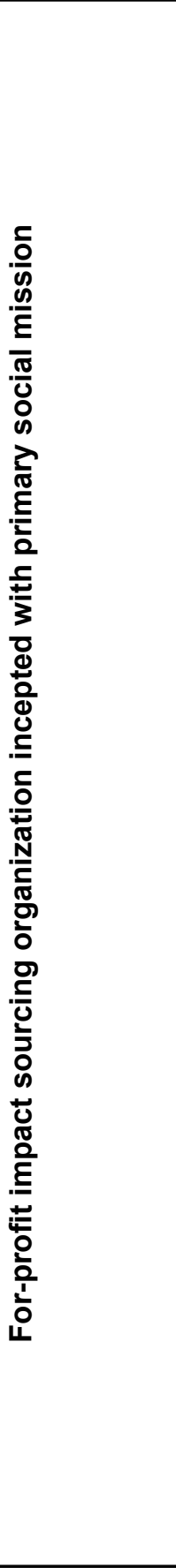 } & $\begin{array}{l}\text { Sandeep \& } \\
\text { Ravishankar } \\
\text { (2015a) }\end{array}$ & $\begin{array}{l}\text { For-profit social } \\
\text { enterprise for } \\
\text { providing employment } \\
\text { opportunities to youth } \\
\text { in rural areas of India }\end{array}$ & $\begin{array}{l}\text { Introduces a process } \\
\text { model of frame alignment } \\
\text { that explains how } \\
\text { different and diverse } \\
\text { framings are used by } \\
\text { impact-sourcing ventures } \\
\text { to influence the local } \\
\text { community. }\end{array}$ & $\begin{array}{l}\text { Positive image related } \\
\text { to progress, family, } \\
\text { material benefit, and } \\
\text { egalitarianism can help } \\
\text { overcome tensions and } \\
\text { misunderstandings } \\
\text { within the community. }\end{array}$ \\
\hline & $\begin{array}{l}\text { Sandeep \& } \\
\text { Ravishankar } \\
\text { (2015b) }\end{array}$ & $\begin{array}{l}\text { For-profit social } \\
\text { enterprise, funded by } \\
\text { social venture capital } \\
\text { for providing } \\
\text { employment } \\
\text { opportunities to youth } \\
\text { in rural areas of India }\end{array}$ & $\begin{array}{l}\text { Introduces process } \\
\text { model of the individual- } \\
\text { level motivational triggers } \\
\text { of impact sourcing } \\
\text { entrepreneurship - the } \\
\text { entrepreneurial actions } \\
\text { that underpin different } \\
\text { phases of venture } \\
\text { creation and the positive } \\
\text { institutional-level } \\
\text { influences. }\end{array}$ & $\begin{array}{l}\text { Personalized values } \\
\text { influence on the } \\
\text { business model. } \\
\text { Intensive period of } \\
\text { embedding and } \\
\text { alliances with local } \\
\text { partners are crucial for } \\
\text { the scalability and } \\
\text { sustainability. Social } \\
\text { encoding and mimicry } \\
\text { determine the } \\
\text { continued commitment } \\
\text { to communities. }\end{array}$ \\
\hline & $\begin{array}{l}\text { Malik et al. } \\
(2016)\end{array}$ & $\begin{array}{l}\text { For-profit social } \\
\text { enterprise for socio- } \\
\text { economic } \\
\text { development of the } \\
\text { marginalized rural } \\
\text { community in India }\end{array}$ & $\begin{array}{l}\text { Theorizes impact } \\
\text { assessment on the } \\
\text { recipients using lens of } \\
\text { capabilities. }\end{array}$ & $\begin{array}{l}\text { Identifies constraining } \\
\text { and enabling } \\
\text { conversion factors and } \\
\text { role of impact-sourcing } \\
\text { organizations in } \\
\text { capability development } \\
\text { of rural community. }\end{array}$ \\
\hline & $\begin{array}{l}\text { Sandeep } \\
\text { and } \\
\text { Ravishankar } \\
(2018)\end{array}$ & $\begin{array}{l}\text { Founders of } \\
\text { enterprise had } \\
\text { "altruistic" motivation } \\
\text { of providing } \\
\text { employment } \\
\text { opportunities to } \\
\text { marginalized youth } \\
\text { living in rural areas }\end{array}$ & $\begin{array}{l}\text { Draws together } \\
\text { transitions-related and } \\
\text { developmental studies } \\
\text { concepts. }\end{array}$ & $\begin{array}{l}\text { Informants used a } \\
\text { series of strategies to } \\
\text { respond and manage } \\
\text { the symbolic } \\
\text { boundaries between } \\
\text { their community and } \\
\text { their impact sourcing } \\
\text { work environment. }\end{array}$ \\
\hline & $\begin{array}{l}\text { Khan et al. } \\
(2018)\end{array}$ & $\begin{array}{l}\text { Public benefit } \\
\text { corporation (for-profit } \\
\text { firm with a primary } \\
\text { social mission) }\end{array}$ & $\begin{array}{l}\text { Introduces a new } \\
\text { conceptual framework } \\
\text { that comprises four } \\
\text { dimensions: primary } \\
\text { mission, success criteria, } \\
\text { resource mobilization, } \\
\text { and innovation approach. }\end{array}$ & $\begin{array}{l}\text { The firm used social } \\
\text { logic for both its } \\
\text { primary mission and } \\
\text { resource mobilization. } \\
\text { It used commercial } \\
\text { logic for its success } \\
\text { criteria, and used both } \\
\text { logics for innovation. }\end{array}$ \\
\hline 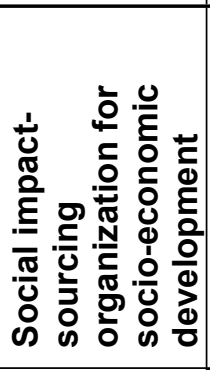 & $\begin{array}{l}\text { Madon and } \\
\text { Ranjini } \\
(2018)\end{array}$ & $\begin{array}{l}\text { Rural BPO, social } \\
\text { enterprise and NGO } \\
\text { supported } \\
\text { outsourcing } \\
\text { enterprise }\end{array}$ & $\begin{array}{l}\text { Identify government } \\
\text { policy institutions' impact } \\
\text { on operations of impact- } \\
\text { sourcing organizations }\end{array}$ & $\begin{array}{l}\text { The government } \\
\text { support is required for } \\
\text { sustainability of rural } \\
\text { enterprises. The paper } \\
\text { identifies the need of } \\
\text { further research for } \\
\text { policy making to } \\
\text { enhance impact } \\
\text { sourcing activities. }\end{array}$ \\
\hline
\end{tabular}




\begin{tabular}{|l|l|l|l|l|}
\hline & $\begin{array}{l}\text { Madon \& } \\
\text { Sharanappa } \\
(\text { 2013) }\end{array}$ & $\begin{array}{l}\text { Non-profit social } \\
\text { enterprise for socio- } \\
\text { economic } \\
\text { development of the } \\
\text { marginalized rural } \\
\text { community in India }\end{array}$ & $\begin{array}{l}\text { Introduces a framework } \\
\text { to conceptualize the } \\
\text { micro-level } \\
\text { developmental } \\
\text { transformation of } \\
\text { individuals and local } \\
\text { communities. }\end{array}$ & $\begin{array}{l}\text { Developmental } \\
\text { advantages to rural } \\
\text { poor communities lead } \\
\text { to policy implications } \\
\text { for governments and } \\
\text { development agencies. }\end{array}$ \\
\end{tabular}

\section{CASE DESCRIPTION}

AlphaCorp is a medical billing outsourcing company incorporated in 2001 as a private limited company and listed on the New York NASDAQ stock exchange in 2014. AlphaCorp's head office is located in the US and is representative of a market-driven business created as a result of a perceived economic opportunity. The company's offshore outsourcing subsidiaries in Pakistan (one in Islamabad and one in Bagh district) provide all back office business process services. Together, the company has more than 1,000 employees split between the three centers (approximately 20 in the US, 800 in Islamabad, and 200 in Bagh district) that provide outsourcing services to more than 900 clients in 40 states of the US. The company's annual revenue was US\$32.5 million as of March 2014.

Bagh (which means "Garden") became a district in 1987. It comprises an area of 1,368 square kilometers, lies within the Himalayas region and surrounded by mountainous terrain. According to the last district census report of 1998; it had a population of 395,000 with 2.6 percent annual growth rate. The average household size was 7.4 per family, and 94 percent of the population lived in rural areas (ERRA, 2007). In 2005, a deadly earthquake destroyed more than 95 thousand homes and caused 9,167 casualties in Bagh district (Planning and Development Department Muzaffarabad, 2013). The Earthquake Reconstruction and Rehabilitation Authority also reported: "besides losing physical livelihood means and social assets including schools, health, facilities and land, people have lost intangible assets such as capacity to work" (ERRA, 2007, p. 13).

The founder of AlphaCorp, who was born in Bagh (but now based mainly in the US), had a strong motivation to share his success with his devastated hometown. Largely as a result of this individual's action, in 2009, AlphaCorp established a center in 
Bagh district in order to: 1) maintain a backup office and 2) aid the socio-economic development of the region by creating employment opportunities for well-educated but unemployed young people, especially women. The organization does not formally or explicitly state this social objective. However, the managers we interviewed during fieldwork in Pakistan openly discussed the social objective as well as the commercial objective of setting up in an area with an educated young workforce.

The region has long suffered from economic migration because many educated people raised in the area choose to gain employment in the public sector or move to other cities in Pakistan in order to find suitable white-collar work. Due to the area's prevailing deeply conservative norms, the majority of parents do not permit their daughters to move to other cities for work, which leaves teaching (in both the public and private sectors) as the only employment option available to educated women.

Pakistan is a male-dominated society that features many stereotypical expectations associated with gender roles (e.g., men are bread-winners and women are homemakers). The prevailing conservative norms of the society and lack of assistive facilities such as transport, childcare, flexibility in working hours, and so on mean that women have few occupational choices in the labor market-particularly in rural or remote areas (Ferdoos, 2005; Rehman \& Roomi, 2012). Women in Pakistan experience systemic gender subordination. The country features a rural/urban divide due to uneven socioeconomic development that varies considerably across social classes and different regions. Furthermore, tribal, feudal, and capitalist social formations have a clear impact on women's lives (Ali, 2013; Mughal, 2014; Sathar \& Kazi, 2000).

Thus, in the specific area we conducted our case study (i.e., Bagh), women experience marginalization for two reasons: 1) the remote location and 2) socio-cultural norms that limit their occupational choice. First, Bagh is $160 \mathrm{~km}$ from Islamabad and subjected to adverse winter weather; landslides frequently block roads due to the area's mountainous terrain. The 2005 earthquake continues to impact the area as well in that many people have grown up as orphans or had their homes destroyed. Second, due to the conventional socio-cultural norms mentioned above, most educated women find it 
challenging to work in the private sector's mixed-gendered organizations or to obtain permission from their families to move to metropolitan cities.

\section{RESEARCH METHOD}

We adopted an interpretive case study research design (Klein \& Myers 1999; Walsham, 1995, 2006) to analyze AlphaCorp. We selected this organization because it provided the opportunity to study both a marginalized population and the institutional logics in detail. For example, the organization's public listing on the NASDAQ stock exchange signifies its market-driven business model and its decision to locate an offshore outsourcing center in the remote mountainous region in Pakistan signifies a social objective commensurate with impact sourcing definitions.

Following the guidance in Walsham $(1995,2006)$, we collected empirical data from a variety of sources. Semi-structured interviews provided the primary source of empirical data that we complemented with detailed field notes that were made during observations and from informal conversations. We subsequently converted all interviews and field notes to electronic format. To obtain a holistic perspective, we conducted interviews with employees at all levels of the organization, including senior management, middle-level managers, and outsourcing employees (female billing executives). One of the researchers, a Pakistani national who speaks Urdu language, resided in Pakistan from September 2013 to March 2014 to undertake fieldwork. This researcher also conducted six further interviews at AlphaCorp's head office in the US in August 2014.

We conducted the interviews following the guidelines in Myers \& Newman (2007). The interviews themselves explored AlphaCorp's objectives and operations, the respondents' experience of working in the GITO sector, the challenges of working for AlphaCorp, and the challenges that AlphaCorp has faced operating in Bagh district. The length of the interviews varied from 20 to 120 minutes depending on the time constraints that the research participants faced. We recorded the interviews with permission and then transcribed them verbatim. We did not receive permission to record two interviews, so we took copious interview notes instead, which were later converted to electronic format. We also obtained and read publicly available secondary 
data sources, including the company's website, internal reports, press releases, and the registration form from the NASDAQ stock exchange website. Table 2 summarizes the demographic information of the interview respondents.

Table 2. List of interview respondents

\begin{tabular}{|c|c|c|}
\hline Interview participants & Location & $\begin{array}{l}\text { Number of } \\
\text { interviewees }\end{array}$ \\
\hline $\begin{array}{l}\text { Female billing executives and team } \\
\text { leads }\end{array}$ & Bagh & 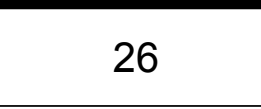 \\
\hline $\begin{array}{c}\text { Female billing executives (based at } \\
\text { two locations) }\end{array}$ & $\begin{array}{l}\text { Bagh and } \\
\text { Islamabad }\end{array}$ & 4 \\
\hline Middle-level managers & Bagh & 5 \\
\hline Middle-level managers & Islamabad & 16 \\
\hline Senior managers & Islamabad & 5 \\
\hline Government official & Muzaffarabad & 1 \\
\hline ICT educational consultant & Islamabad & 1 \\
\hline Middle managers & US & 3 \\
\hline Senior managers & US & 3 \\
\hline \multicolumn{2}{|l|}{ Total } & 64 \\
\hline
\end{tabular}

\subsection{Data analysis}

We analyzed the data as we collected it to generate emergent insights to guide our subsequent data-collection efforts (Klein \& Myers 1999; Silverman, 2006). Table 3 summarizes our data-analysis process. We used NVivo 10 to organize and code the large amount of qualitative data that we gathered (Bazeley \& Jackson, 2013).

Reay \& Jones (2016) classify how one can identify, describe, and measure institutional logics. We follow the guidelines on pattern inducing that involves analyzing and coding the segments of textual data that show behavior, values, assumptions, and beliefs related to various institutional systems, an approach also documented in Reay \& Hinings (2005) and Smets et al. (2012, 2015).

We began data analysis by open coding text segments of fieldwork data that referred to values, beliefs, assumptions, and practices thus applying a bottom-up pattern-inducing technique to identify institutional logics grounded in the qualitative data. We then followed the pattern-inducing technique to identify AlphaCorp's management practices in our qualitative data that responded to these institutional logics again 
following the guidance in Reay \& Jones (2016). We organized and merged all codes into four categories: "family institutional logics", "community institutional logics", "profession institutional logics", and "alignment of management practices".

After coding the qualitative data and organizing it into these categories, we next generated explanatory theory to determine how and why the observed phenomena occurred following Avgerou (2013). In doing so, we focused on identifying social mechanisms, which refer to processes or activities that link cause and effect and construct a causal explanation of social phenomena (Avgerou, 2013; Hedström \& Swedberg, 1998). Inspired by Smets et al.'s (2015) inductive approach to deriving mechanisms, we abstracted further by clustering AlpahCorp's practices based on similar actions. We identified these clustered practices as mechanisms on the basis of how they aligned AlphaCorp with different institutional logics using our own interpretation and the interpretation of interviewees. We found that we could abstract the practices into three mechanisms: synchronization, bridging, and embedding. To do so, we had extensive discussions both face-to-face and via Skype where we spent considerable effort iterating between theoretical abstractions related to institutional logics. As versions of the candidate mechanisms were produced, we engaged in a dialogue between ourselves and produced a working paper that was presented at seminars at our own university and others. Walsham (2006) suggests that "the researcher's best tool for analysis is his or her own mind, supplemented by the minds of others when work and ideas are exposed to them" (p. 325) and we used this approach in the seminars to challenge our causal explanation in view of alternative mechanisms.

Figure 1 presents example codes and a final template of the analyzed data (King, 2012). Table 4 summarizes the institutional logics, the aligned management practices, and the mechanisms. Table 5 summarizes the definitions of three mechanisms. 
Table 3. Summary of data analysis

\begin{tabular}{|c|c|c|}
\hline $\begin{array}{c}\text { Data-analysis } \\
\text { steps }\end{array}$ & Actions & Outputs \\
\hline $\begin{array}{c}\text { Identify } \\
\text { institutional } \\
\text { logics and } \\
\text { aligned } \\
\text { management } \\
\text { practices }\end{array}$ & $\begin{array}{l}\text { 1. Following a bottom-up pattern inducing } \\
\text { approach, we open coded all text } \\
\text { segments related to value, beliefs, } \\
\text { assumptions, rules, and practices to } \\
\text { identify institutional logics. } \\
\text { 2. Using a practice perspective, we } \\
\text { followed a pattern-inducing approach to } \\
\text { code the data to identify AlphaCorp's } \\
\text { management practices (organized } \\
\text { constellation of actions). }\end{array}$ & $\begin{array}{l}\text { Figure } 1 \text { presents } \\
\text { codes and a final } \\
\text { template of the } \\
\text { analyzed data. }\end{array}$ \\
\hline $\begin{array}{c}\text { Identify } \\
\text { mechanisms }\end{array}$ & $\begin{array}{l}\text { 1. We abstracted the practices with the } \\
\text { notion of mechanisms (identify the } \\
\text { process through which the observed } \\
\text { outcome was generated); we specifically } \\
\text { identified those mechanisms that show } \\
\text { the relationship between AlphaCorp's } \\
\text { management practices and the } \\
\text { institutional logics. } \\
\text { 2. We clustered the management practices } \\
\text { into mechanisms based on similar } \\
\text { actions (i.e., synchronization, bridging, } \\
\text { embedding). }\end{array}$ & $\begin{array}{l}\text { Table } 4 \\
\text { summarizes the } \\
\text { institutional logics } \\
\text { and relevant } \\
\text { mechanisms. } \\
\text { Table } 5 \text { defines } \\
\text { the identified } \\
\text { mechanisms. }\end{array}$ \\
\hline
\end{tabular}


1 Community institutional logics

1.1 Conventional attitude of the community

1.1.1 Gender segregation

1.1.2 Respect and honor of women

1.1.3 Adhering to cultural and religious values

1.2 Assumptions about organizational objectives

1.2.1 Suspicion/speculation over organizational objectives

1.2.2 Confusion about organizational business

1.3 Distrust international organizations

1.3.1 Relating past experience

1.3.2 Concerns regarding damaging of local culture

\section{Family institutional logics}

2.1 Family expectations

2.1.1 Family commitments and liabilities

2.1.2 Work-life balance

2.2 Family reservations

2.2.1 Over-protective parental attitudes

2.2.2 Safety and other concerns

2.3 Observe family values and norms

2.3.1 Adherence to family, social, and religious values

2.3.2 Follow family norms

\section{Profession institutional logics}

3.1 Attributes of a profession

3.1.1 Career progression

3.1.2 Satisfy financial needs

3.2 Personal and professional skillsets

3.2.1 Personal capabilities and knowledge

\subsubsection{Professional skills and} exposure

3.3 Stereotype about women-oriented professions

3.3.1 Teaching as an honorable profession

3.3.2 Assumptions about female participation in white-collar jobs

4. Alignment of management practices with institutional

\section{logics}

4.1 Define culturally sensitive management practices

4.1.1 Hiring of local management

4.1.2 Separate shifts for men and women

4.2 Provide awareness to the community

4.2.1 Open monthly meetings with the community

4.2.2 Familiarization tours of the organization for community

4.3 Gain local community's acceptance

4.3.1 CSR activities

4.3.2 Free English language course for students

4.4 Define female-friendly management practices

4.4.1 Dedicated morning shift for

female employees

4.4.2 Conveniently located center

4.5 Provide resources to satisfy families' concerns

4.5.1 On-campus meals

4.5.2 Transport facilities

4.5.3 Safety in the work place

(security cameras and guards)
4.6 Gain families' trust

4.6.1 Allow family member to accompany female employees on trips

4.6.2 Provide opportunity to perform religious ritual with a family member

4.7 Define lucrative financial and career attributes

4.7.1 Offer career growth opportunities and future employability perspectives

4.7.2 Offer attractive salary and perks

4.8 Provide personal and professional grooming

4.8.1 On-the-job training

4.8.2 Soft-skills training

4.8.3 Exposure opportunities

4.9 Influence gendered career perceptions

4.9.1 Hiring of women as IT and BPO service providers

4.9.2 Reserved jobs in morning shift for women empowerment

Figure 1. Final template of analyzed data 
Table 4. Institutional logics, mechanisms, and alignment of management practices

\begin{tabular}{|c|c|c|c|}
\hline \multicolumn{2}{|c|}{ Institutional Logics } & Mechanisms & $\begin{array}{l}\text { Alignment of } \\
\text { Management } \\
\text { Practices }\end{array}$ \\
\hline $\begin{array}{l}\text { - Community } \\
\text { - Family } \\
\text { - Profession }\end{array}$ & $\begin{array}{l}\text { - } \begin{array}{l}\text { Conventional } \\
\text { attitude of the } \\
\text { community }\end{array} \\
\text { - Family expectations } \\
\text { - Attributes of a } \\
\text { profession }\end{array}$ & Synchronization & $\begin{array}{l}\text { Define culturally } \\
\text { sensitive } \\
\text { management } \\
\text { practices } \\
\text { Define female- } \\
\text { friendly } \\
\text { management } \\
\text { practices } \\
\text { Define lucrative } \\
\text { financial and } \\
\text { professional } \\
\text { attributes }\end{array}$ \\
\hline $\begin{array}{l}\text { - } \text { Community } \\
\text { - Family } \\
\text { - Profession }\end{array}$ & 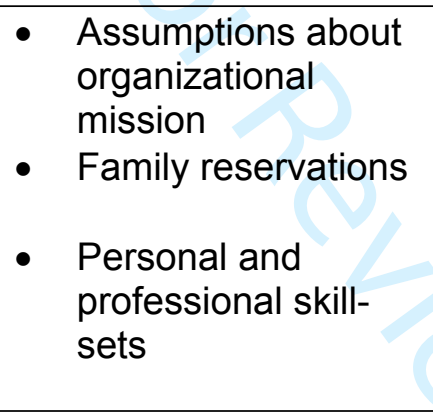 & Bridging & 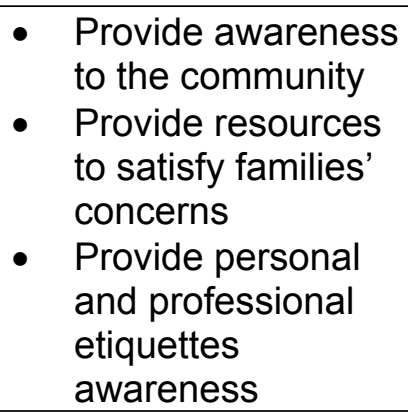 \\
\hline $\begin{array}{l}\text { - Community } \\
\text { - Family } \\
\text { - Profession }\end{array}$ & $\begin{array}{ll}\text { - } & \text { Distrust international } \\
\text { organizations } \\
\text { - } \\
\text { Observe family } \\
\text { values and norms } \\
\text { - } & \text { Stereotypes about } \\
\text { women-oriented } \\
\text { professions }\end{array}$ & Embedding & $\begin{array}{ll}\text { - } & \text { Gain local } \\
\text { community's } \\
\text { acceptance } \\
\text { - } & \text { Gain families' trust } \\
\text { - } & \text { Influence gendered } \\
& \text { career perceptions }\end{array}$ \\
\hline
\end{tabular}

Table 5. Definitions of mechanisms

\begin{tabular}{|l|l|}
\hline Mechanism & Definition \\
\hline Synchronization & $\begin{array}{l}\text { The mechanism by which a GITO organization-engaged in impact } \\
\text { sourcing work—adjusts management practices with the institutional } \\
\text { conditions }\end{array}$ \\
\hline Bridging & $\begin{array}{l}\text { The mechanism by which a GITO organization-engaged in impact } \\
\text { sourcing work—addresses the limitations caused by institutional } \\
\text { logics by providing support and sometimes additional resources to } \\
\text { the marginalized individuals }\end{array}$ \\
\hline Embedding & $\begin{array}{l}\text { The mechanism by which management practices of a GITO } \\
\text { organization-engaged in impact sourcing work-inculcate change in } \\
\text { the institutional logics }\end{array}$ \\
\hline
\end{tabular}




\section{FINDINGS}

In this section, we describe and explain how the institutional logics in Bagh district influenced AlphaCorp and the response to that influence. We developed four themes to organize the data: community institutional logics, family institutional logics, profession institutional logics, and alignment of management practices with institutional logics. The fourth theme was further abstracted into three mechanismssynchronization, bridging, and embedding - that show how AlphaCorp responded to the influence of family, community and profession institutional logics.

\subsection{Community institutional logics}

Brint (2001) defines communities as "aggregates of people who share common activities and/or beliefs and who are bound together principally by relations of affect, loyalty, common values, and/or personal concern" (p. 8). From analyzing the qualitative data, we found that community logics had the greatest influence on AlphaCorp management practices. Many respondents reported that the community was "traditional and conservative" like many other rural communities in Pakistan (Mughal, 2014). As we continued our research, we found that the community held negative perceptions of work practices in the private sector developed in part from bad experiences with international non-governmental organizations (NGOs) that had arrived for relief operations after the 2005 earthquake. Many NGOs had provided emergency assistance to the community and hired local men and women to assist in the aid and rehabilitation work. However, the majority of the international NGOs brought practices and modern culture that many in the community felt had not considered local norms and traditional values. For example, women often had to work in an office and community with male employees at "odd hours" (i.e., late into the evening)-something that many in the local community found "disrespectful".

This negative perception of private-sector office jobs adversely affected the image of AlphaCorp when it first began operating in Bagh, and some local parents forbade their daughters from working there because they believed, if they did so, it would bring "Western culture" to the community, which would conflict with their traditional community cultural and family norms. The Manager of Operations (MO) commented: 
When we started in 2009, it was a difficult time. Difficult in the sense those NGOs were also operating during that time and their image was not good. People don't like their administrative and operational style; they even had fixed some deadlines for NGOs to leave the town. During our early days, people asked if they could visit us and if we could guide them about the operations, the type of work and how we would provide a respectable work environment for both male and female employees. (MO1)

Community beliefs in Bagh, expressed by many interviewees, are that men and women should not mix socially-a finding that concurs with prior research on similar Pakistani rural contexts (Ferdoos, 2005). Furthermore, respondents stated that at the time of AlphaCorp's start up, men and women working together in offices was not considered appropriate. One female billing executive (BE) shared her experience:

I am the first girl in my family to work in an office. My father is very broadminded. He brought me up like a son. When I wanted to work in the office, he advised me to first check the company's environment: did boys and girls work together? Our community usually has many reservations over it. (BE 15)

Paradoxically, it appeared from our observations and informal talks, if financially possible, people preferred to send their children away for their higher education to other cities where most of the universities were co-educational. Some female respondents had already obtained university degrees from co-educational higher education institutions in other cities. We investigated this phenomenon further in order to explore the reasons for such a paradoxical community logic given that it seemed acceptable for the community to send their daughters to other areas to receive education in gender-mixed institutions but inappropriate to allow them to work in offices where both men and women worked together. The increasing trend for women education in the rural communities of Pakistan has driven women's participation in the socio-economic dynamics of the country (Mughal, 2014). Respondents mentioned a large number of schools, colleges, and computer training centers that had been established in the region as a result of the rehabilitation efforts implemented after the 2005 earthquake. The ready availability of education has helped to support women education and has also motivated local people to send their children to other cities. Immediately after the earthquake, a large number of 
local people migrated to Islamabad and Rawalpindi-the nearest large metropolitan cities-to enroll their children in the educational institutions located there. However, even for those that had received education in other cities, the institutionalized community logics regarding gendered division of labor in Bagh endured and remained clear: women were responsible for domestic work and men for earning.

One BE, who had graduated in commerce from a university located in a major city in Pakistan, shared her experience of joining AlphaCorp:

When I decided to work in AlphaCorp, no one in my village had appreciated me except my mother. I was engaged and my fiancé's mother was very annoyed about my job. Then I told them that my mother was a single parent who had struggled a lot to provide us with education; now it was my turn to support my younger siblings' education. So I refused to leave my job and broke off my engagement because they argued that girls don't go out to earn a living in their family. They told me that I could study as much as I want but I should not move out of the village for a job. (BE 20)

Thus, AlphaCorp management were confronted with the community-related challenges of gendered institutional logics based on their conventional beliefs regarding male and female segregation and the more recent impact of insensitive NGO practices.

\subsection{Family institutional logics}

Friedland and Alford (1991) identify the institutional logic of the family as associated with unconditional loyalty to family members-a conceptualization that Miller et al. (2011) build on in referring to it as "nurturing, generativity, and loyalty to the family" (p. 4). Although the family is often the center of social life for men and women, the family usually plays a more significant role in women's lives in most conventional societies (Weiss, 1994). Pakistan is a predominately conventional and patriarchal society; in Pakistan, parental authority goes unquestioned (Ferdoos, 2005; Mughal, 2014). Women in Bagh had to obtain permission from their families (more specifically, their fathers) in order to work at AlphaCorp, and many parents initially had concern about the work environment when their daughters asked them if they could join the company. The Vice President (VP) of AlphaCorp mentioned the conventional family order of the Bagh district: 
We have tried a lot to facilitate employment but then it also depends on the home environment. It depends if parents allow their girls to work. (VP)

We observed how the institutional logics became entangled. For example, the area's existing community logics (e.g., stereotypical gender roles and community prejudice against the private sector) directly influenced the family logic that prohibited daughters to work in an outsourcing organization. One BE shared her experience:

There was no trend of women working in offices in our family. When I told my family that I was intending to do a job, they said, 'Why? Why do you need to work?' (BE 14)

Further, an MO said:

Girls working in the office here presented a unique experience and many families thought for a while before allowing their daughters to work for the company. (MO2)

We also uncovered a surprising dichotomy of family logics. Contrary to the family and community logics that we outline above, many women employees reported that they had joined AlphaCorp because their families had encouraged them to work there. Further investigation revealed that the majority of respondents who had mentioned family constraints were senior outsourcing employees at AlphaCorp with long tenures-who had joined the company early on. The respondents who asserted that their families had supported their decision to work for AlphaCorp were among the more recently recruited employees. These findings suggest that family institutional logics have changed gradually such that the recently hired female outsourcing employees reported less resistance and even encouragement from their families when they joined AlphaCorp.

\subsection{Profession institutional logics}

Many educated women in the region join the teaching profession in either the public or the private sector, and the interviews indicated that local people consider teaching to be both a "respectable" and a "female friendly" profession given the society's conventional cultural and normative influence (Ferdoos, 2005; Mughal, 2014; Rehman \& Roomi, 2012). Most respondents did not consider the financial 
recompense for teaching to be particularly high. Instead, they said that the working hours and majority female workforce constituted the reasons why families in the region preferred their daughters to follow this career path. For example, one BE said:

My family wanted me to join the teaching field because it is a most respectable profession, where you can manage both home and work. (BE 23)

The profession logic of being a teacher and being considered "honorable" is thus compatible with the community logics. It satisfies the community institutional logics that segregates men and women in the workplace and also offers a manageable work-life balance-a finding that concurs with Rehman \& Roomi (2012). It also satisfies family logics because family members believe that women teachers can also devote time to their families.

We found evidence that individual agency, physical and environmental factors shaped institutional logics. For example, several respondents had continued their higher education despite their job in AlphaCorp. Many female respondents expressed their ambition to become teachers because they enjoyed that work; some also expressed the view that it would be easier for them to manage a teaching career once married than working in the outsourcing sector, which often demands long working hours in order to satisfy foreign clients.

We also found evidence that individual agency contributed to effecting change in profession logics. For example, many female respondents also shared their desire to work in an office on IT-oriented work. They aspired to work in IT companies and to be competitive in the professional job market. However, the professional IT skill levels of the Bagh workforce are not comparable to those of the workforce in metropolitan cities because of relative differences in the standard of education and opportunity for professional experience. This discrepancy can be explained by the limited employment opportunities in Bagh for women to gain business IT exposure other than AlphaCorp. Secondly, family and community logics constrain the mobility of females from moving to any metropolitan city for work reducing opportunity for gaining IT related experience. As we discuss above, the newer female outsourcing employees faced much less resistance from both their families and the wider community which indicates a change in these logics over time.

\subsection{Practices and mechanisms}


The research findings report various management practices (details are provided in Table 2) that AlphaCorp management adopted to respond to the institutional logics discussed above. Unraveling the causal process involved in determining how and why practices are implemented, we clustered the practices into three mechanisms: synchronization, bridging, and embedding that are described below.

\subsubsection{Synchronization mechanism}

From analyzing our data, we found that AlphaCorp's management had a significant ability to synchronize management practices and institutional logics that we discuss above to fulfill impact sourcing's "dual value" objectives: that is, to create both social value and commercial profitability. We refer to this mechanism as synchronization and define it as the mechanism by which the GITO organization engaged in impact sourcing work adjusts management practices to mirror existing institutional logics.

As summarized in Figure 1, AlphaCorp implemented culturally sensitive management practices, female-friendly management practices, and lucrative financial and professional attributes to achieve synchronicity with the existing community, family and profession institutional logics. An example to illustrate this is the adaptation of management recruitment practices. In the early stages of startup in Bagh, AlphaCorp management decided to transfer senior management from the existing center in metropolitan Islamabad to the Bagh center. As the tensions with family and community logics became apparent over time, a decision was made to recruit management locally since they would be known to the community and better equipped to understand the local culture, norms, and traditions present in the area. Although the personnel from Islamabad were ethnically Pakistani, this example emphasizes the situated importance of historical background on institutional logics (such as the enduring memory of the earthquake trauma and problems with NGOs) and ongoing reflexivity in the community and family logics regarding local perspectives of "what is acceptable and what is not". The general manager (GM) explained the synchronization in management practices as follows:

The cultural issues? Yes, of course. The first step was to hire local management. Those managers absolutely understand the local area's norms, culture, and all the different values. So being a person from the same area, for example, our human resources (HR) manager is from the same 
area, she knows everything; from a girl's point of view, what is acceptable, what is not acceptable in the society. In the same way the administration manager belongs to the same area, and also knows the culture. Thus, local management is running the Bagh center. (GM)

When we conducted our field work, we met the HR manager who was a former school principal. She had lived in Bagh all her life and we were told by many interviewees that the majority of families in the community knew her well with many parents even remembering her from their school days. Almost all of the female BEs stated that their parents knew and trusted this individual reinforced by long term shared experiences in Bagh and, thus, felt "very safe and comfortable" about sending their daughters to work under her supervision. One BE shared her experience:

The reason why I applied [to work] here is its environment. They take good care of girls. I had not got permission to work somewhere else but my family allowed me to work here very happily. Our Madam [HR manager] is concerned about us and gives us extra care; she also gives priority to our honor, cultural and religious values. (BE 5)

These words further demonstrate how AlphaCorp modified its management practices to the needs of the local context. AlphaCorp has remained attentive to commercial priorities and globally focused on US clients satisfaction but also attended to the local in what Robertson (2012) refers to as a process of "glocalization". This reflects a commercial need for-and practices of-recruiting and retaining local people to satisfy the local institutional logics.

Another example shows how AlphaCorp maintained its office environment in accordance with local community and family logics. To address the enduring community prejudices against private-sector work practices, AlphaCorp's management ensured that their practices respected the norms and values intrinsic in the community logics. Practices included allowing local women employees to wear the traditional religious mode of dress (usually head cover or hijab), introducing a dedicated women-only morning shift, in which female employees could work independently without the presence of men, and not expecting women to stay late in the evening to ensure they could fulfill family expectations. 
With regard to work conditions and pay, AlphaCorp offered relatively lucrative career growth and financial compensation (e.g., a wage rate in Bagh equal to those that it offered in the main Islamabad office) to ensure it satisfies individuals' financial (AlphaCorp salaries are higher than those of local school teachers) and career progression needs. However, we found no evidence that AlphaCorp synchronized its practices with other profession logics of teaching (namely, the short working hours and work-life balance assumed true of the teaching profession within the family and community logics) due to the demand for and the nature of work involved in the commercially driven global outsourcing industry. As a result, many women outsourcing employees we interviewed mentioned that, since career growth and high earnings did not motivate them, they intended to switch to the teaching profession once they get married. The respondents mentioned that they are not entitled to public holidays much to the chagrin of their families. For example, during Eid (a religious festival in Pakistan) a three to four day holiday is a commonly accepted norm when families would travel to different cities to celebrate with their parents and grandparents. AlphaCorp's employees receive only a one-day Eid holiday in order to fulfil contracts with US clients.

"My cousins and other family members complain that I don't join them during Eid and missed most of my family functions. I try to explain them that I don't do it on purpose; due to my work nature it is not easy to take leaves. But they don't understand. " (BE 9)

\subsubsection{Bridging mechanism}

Analysis of the data highlighted AlphaCorp's management practices to address the constraints presented by institutional logics. We observed that managers allocated resources to bridge these shortcomings through, for example, "awareness sessions" aimed at overcoming the prejudices against private sector employment rooted in the post earthquake NGO practices. These meetings were offered to the general community as events and as smaller meetings specifically for parents. The meetings focused on improving awareness of the company's mission and function. The operations manager described practices to build awareness as a gradual process:

At the start, we arranged monthly meetings; people visited us and saw our work... We faced problems in the first year; people made negative comments. 
Then, gradually, the community came to understand AlphaCorp and its operations. (MO1)

Other bridging examples are shown in the AlphaCorp's training to improve employees' professional and personal skills. The same operations manager illustrated the bridging mechanism in action:

We need to put extra effort in for newly hired employees. We don't need to put more effort into the Islamabad center's newly hired employees because their computer and professional knowledge is already up to the mark. However, here, we have to teach them things from computer knowledge to office etiquette because of their limited personal and professional skills. (MO 1)

The relative deficiency related to ICT knowledge and professional exposure due to constraining social norms was accentuated by relatively poor bandwidth and ICT resources. This resulted in the need for bridging practices. As AlphaCorp were the only private sector outsourcing organization in Bagh - besides a few small branches of private banks and negatively perceived NGOs - professional skills such as communication and presentation were absent in most candidates and needed to be bridged. Other profession related logics had to be bridged such as the training on the US system of medical billing. When potential employees attended information sessions held at the AlphaCorp offices, it became apparent that they lacked understanding of healthcare information processing and medical billing for insurance companies in the US. The historical practices of rural Pakistan's health institutions differ from US and the process of using insurance companies to pay medical bills is uncommon. Institutions in Pakistan typically involve attending public hospitals to obtain free treatment or pay in cash for visits to private medical centers.

The respondents mentioned the traditional family and community norms related to gender in Bagh that expected women to be accompanied by the men or elder women of the family. Besides the influence of beliefs and values there was also a pragmatic problem of lack of public transport and the effect of mountainous terrain which in bad winter weather presented risk of landslides. A "pick-up and drop-off" service had the specific goal of overcoming the community and family logics related to concerns about ensuring women could travel to and from work safely. As a consequence, over time, both the community and the families of female employees 
became increasingly satisfied that AlphaCorp had showed sufficient concern for their employees and had provided a safe working environment for their daughters. Numerous female employees told us they felt "relaxed and satisfied" because the company van picked them up from their homes and returned them back in the evening. A BE reported:

Only a few jobs, mostly in teaching, were available before AlphaCorp opened the office here. Due to the unavailability of frequent public transport, you had to commute by walking. AlphaCorp provides a transport facility and a free lunch. We don't have any problems with commuting. We come here tension free and enjoy working the whole day and into the evening, arriving home in a respectable way by using company's transport. (BE 5)

Our data analysis showed bridging practices to meet the differences in skill levels between the Bagh employees and those from the metropolitan locations in Islamabad. As a result of cultural constraints and relatively low-quality education, AlphaCorp needed to invest resources into training the employees recruited for the Bagh center. For instance, the company provided significantly longer periods of initial training than was the norm in the metropolitan center. The company bridged interpersonal and job-specific professional skill gaps through continual on-the-job training, extended soft-skill training, and familiarization visits to the metropolitan center in addition to the initial business process training. One BE described these elements:

They provided us with one month's training (generally two weeks in Islamabad) related to medical billing. But they guide us in almost everything. Even our madam (supervisor) teaches us how to speak and how to behave professionally. They treat us very gently. Apart from job training, they guide us in soft skills. They even taught us how to introduce ourselves. (BE 14)

The employees have rewarded the extra training in that most meet the service-quality standards of the metropolitan center and, indeed, the US standards. Thus, improvements in quality of work and the wider skills of the outsourcing employees, gained as an outcome of this additional training, created social value but also met the commercial needs of AlphaCorp. 
AlphaCorp also provides career progression opportunities to its dedicated employees. The company has implemented standard human resource management processes of annual performance evaluation and appraisals. Almost all the team leaders and operation managers we talked during data collection were promoted from the entry level position (billing executives). During data collection in the US, we met the female operation manager of Bagh centre in the US main office, whom we initially met in Bagh during the data collection visit to Pakistan. She was selected along with few other male managers from Pakistan and transferred to the US for the period of four months to be involved in the process of initial public listing at NASDAQ stock exchange and AlphaCorp's mergers and acquisitions program.

\subsubsection{Embedding mechanism}

Finally, AlphaCorp management practices gain community trust and influence gendered career perceptions. We classify these practices into the embedding mechanism: a mechanism by which management practices inculcate change in existing institutional logics.

In order to gain the community's acceptance, AlphaCorp managers became involved in many community service initiatives, such as providing free English training in the summer for students, paving the roads, providing medical facilities to local people, and making company vehicles available to transfer patients to the nearest city hospital for emergency or specialist treatment. The HR manager from Bagh commented on AlphaCorp's "community-friendly" approach as follows:

AlphaCorp always think about the community, not only their employees. In the case of any bad situation or emergency, we always help out the community. People think positively about AlphaCorp because of these good deeds and community-supportive attitude. It's not just me talking about this. The majority of people in the community have the same response. (HR Manager)

One female employee mentioned another AlphaCorp's initiative used to gain family and community acceptance:

One of the girls in our batch was selected in a lucky draw to perform Hajj at the company's expense [Hajj involves Muslim pilgrims' travelling to Saudi Arabia to perform a religious ritual]. She went with her father and the company 
invited all our families to a ceremony. My mother came with me; she likes the company environment. (BE 13)

AlphaCorp's managers had devised a series of "appreciation activities" and awards, such as employee of the month and shift of the month. The whole outsourcing shift that won the latter award received a free recreational trip that the team members chose. The female BEs based in the Bagh center could also bring one female family member (usually their mother or sister) along with them on these trips, so that their families would give them permission to participate. These management practices had improved families' trust in AlphaCorp and reduced their reservations about the company linked to the enduring prejudices caused by the NGOs experience. Along with the social objective of increasing the empowerment of previously marginalized female outsourcing employees, this action also reflects a commercial objective because it motivated all employees to try to win the monthly shift award safe in the knowledge that, if they were successful, they would be allowed to enjoy the prize. One BE revealed:

We are allowed to bring our mothers on every company entertainment trip at the company's expense. My mother went to Attock and Rawalpindi with me. She liked it very much and always praises AlphaCorp. Now it is very easy for me to get permission to go on the company's other tours. My family trust AlphaCorp and understand that these business and recreational trips are a part of the professional life. (BE 13)

AlphaCorp attempted to "break the glass ceiling" for women in the region by providing them with work opportunities in a global outsourcing company. It helped to change the stereotypes associated with the female professions, the nature of work that women should do, and the gendered career perceptions and overall mindset of the community and families (i.e., the profession institutional logic). One female outsourcing employee mentioned the change as follows:

Actually, it was not the culture here earlier to work in the private sector because there were no such office jobs available for girls. Women could only adopt teaching as a profession, in public and private schools. Women working in offices here was a unique kind of experience, and many people thought for a [long] while before allowing their daughters to work at the company. But 
since AlphaCorp has created employment opportunities for women here, and put conscious effort into encouraging female inclusion, the overall mindset about professional women and women's professions is gradually changing. When I completed my graduation, my uncle suggested to me that I should join AlphaCorp. (BE 23)

\section{DISCUSSION AND CONTRIBUTIONS}

In this paper, we examine the interplay between institutional logics in a remote area in Pakistan and management practices in a market-driven GITO organization implementing impact sourcing work.

This study presents novel contributions to the impact sourcing and institutional logics literature. Recognizing that impact sourcing is a nascent topic in IS research, we respond to calls from Madon \& Sharanappa (2013), and Sandeep \& Ravishankar (2015a) for further research into novel contexts of impact sourcing. With this paper, we answer (at least in part) the call from Sandeep \& Ravishankar (2015a) for further impact-sourcing research that focuses on the attitudes and lived experience of marginalized groups (i.e., women) other than the economically marginalized. Specifically, we extend prior work focused on the logics of the context (Sandeep \& Ravishankar 2015a; Khan et al. 2018) with an explicit focus on the logics associated with women in impact sourcing as experienced in the context of rural Pakistan. The women in our sample experienced marginalization due to their remote geographical location and the patriarchal cultural norms about their gender (Ferdoos, 2005; Mughal, 2014). Although both men and women in the region had limited opportunities to engage in private-sector work, the local institutional context did not support women moving to other cities to find work. Impact sourcing clearly allowed this marginalized group to enter gainful employment.

The study addresses the research need, identified in prior studies, for analysis of "more typical profit-oriented ventures" (Carmel et al., 2014; Sandeep \& Ravishankar, 2015a). We respond to this call by exploring the tensions of the "dual value orientation" of impact sourcing work in a mainstream market-driven GITO. Drawing on the concepts of institutional logics, the study sought to understand family, community and profession institutional logics of the research context that were grounded in the data and have influenced operations of the GITO engaged in 
impact sourcing work (Khan et al., 2018, Sandeep \& Ravishankar, 2015b). The theoretical concepts of social mechanisms (Avgerou, 2013) and practices (Reckwitz, 2002; Schatzki, 1996) guided the interpretive analysis of management practices with the institutional logics. We identify three mechanisms-synchronization, bridging, and embedding - that demonstrate how management practices of the market-driven GITO organization respond to the institutional logics, while keeping the commercial objective intact. Inspired by Henfridsson and Yoo's (2014) process theory, we integrate contextual conditions (institutional logics), mechanisms, and aligned management practices in a process framework to explain the interplay between institutional logics and management practices of GITO (depicted in Figure 2). The double-headed arrows in Figure 2 show that these mechanisms are interdependent and mutually enforcing. The framework also includes the possibility of change in some institutional logics as a result of impact sourcing activities.

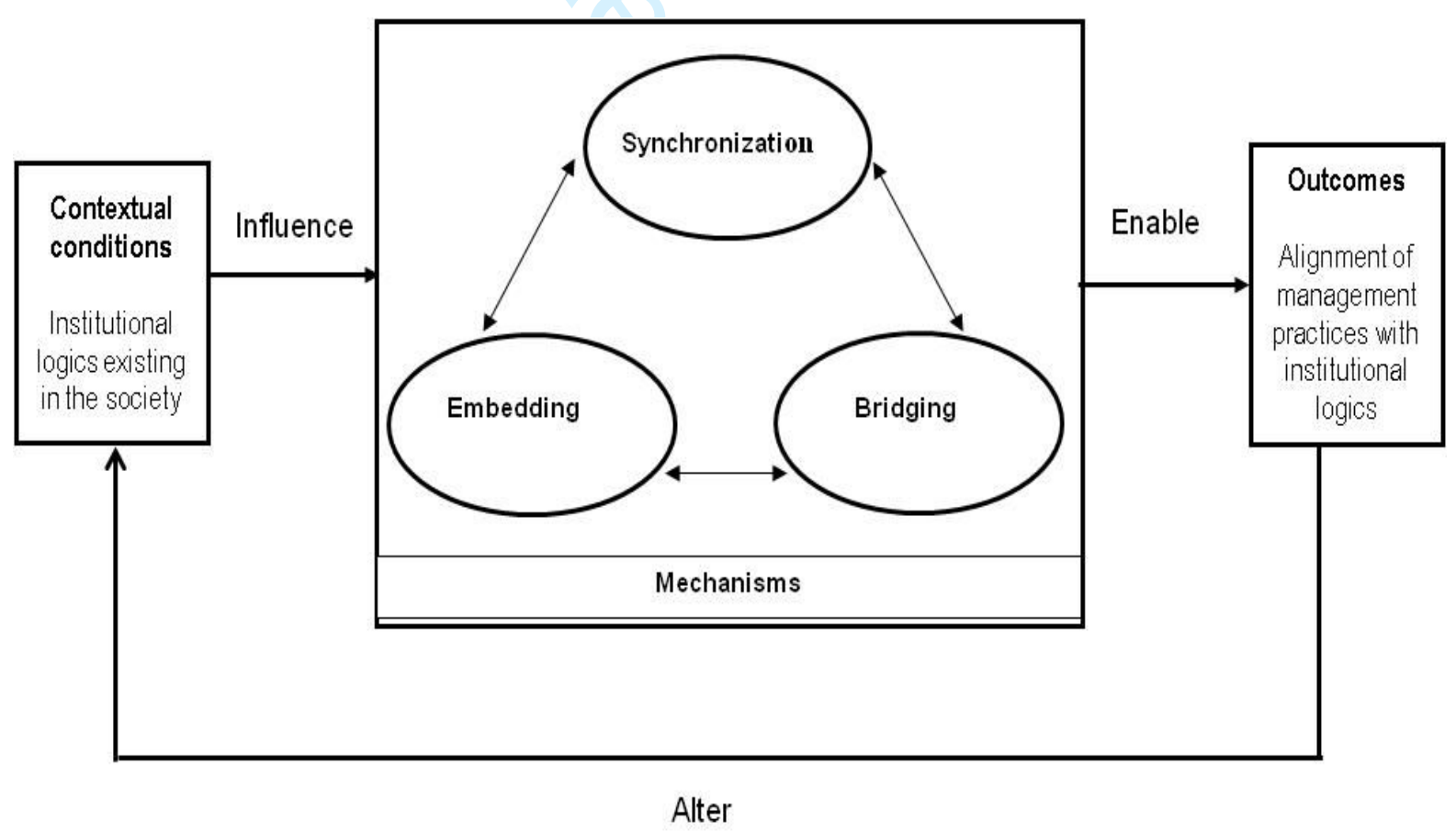

Figure 2. The process framework that shows how institutional logics interplay with management practices

The first mechanism, synchronization, refers to the ability to mirror management practices to the institutional logics in the operating context. This concurs with Sandeep et al. (2013) and Sandeep et al. (2015a) who identify 
impression management techniques to manage community relationships in impact sourcing by creating a positive image within the community. We build on this previous work by providing a detailed analysis of management practices and their congruence with prevailing social and cultural norms related to women as explained above. The findings here concur with Lacity et al. (2012), in that, if a community rejects an outsourcing organization due to a lack of congruence with local institutional logics, then families will not permit their children to work.

Our study also reports examples of tensions in managing the dual value orientation of impact sourcing where AlphaCorp did not synchronize practices to institutional logics, such as lack of provision of flexi-hours for womens' work life balance and matching norms for public holidays due to AlphaCorp's primary mission of economic value creation. Secondly, attempts to synchronize practices with profession logics by offering lucrative salaries and career-growth options failed to synchronize with profession logics - which the local female employees found more important-that made the teaching profession attractive to them. AlphaCorp could have offered greater work-life balance as recommended by prior outsourcing research (Howcroft \& Richardson, 2008; Valk \& Srinivasan, 2011). However, in this case AlphaCorp's management clearly did not consider this course of action viable to attain the commercial objective.

The second mechanism, bridging, illustrates how GITO organizations bridge the gaps and constraints of institutional logics. We identify in this mechanism the need to allocate resources to adopt prudent management practices in impact sourcing work so that they can achieve their social objectives without discarding commercial objectives. There is evidence that GITO organizations require additional resources (financial and human) for bridging the constraints posed by institutions thus, challenging the assumption of reduced costs by sourcing from rural areas (Lacity et al., 2012; Lacity et al., 2010).

The investment of additional resources in bridging mechanism to achieve social objectives seems contradictory to our previous discussion of synchronization mechanisms where AlphaCorp did not offer the management practices of flexi hours for women to sync with profession logics of teaching and to encourage work life balance. This example indicates that whenever there are tradeoffs of commercial and social objectives in practicing impact sourcing work, the market-driven GITO 
organizations are likely to favor the commercial objective. However, we found that AlphaCorp invested additional resources (e.g., long training duration, additional training, and transport services) to bridge the constraints of profession and community logics. AlphaCorp's investment to address constraints caused by the institutional logics shows "dual value" inclination toward social objective but it is also indicative of a long term strategy of developing the workforce to deliver high quality services to the clients thus equally suited to commercial objective.

Making sense of how AlphaCorp allocated resources for practices under the bridging mechanism revealed the bi-directional influences on social and commercial objectives. For example, AlphaCorp benefitted commercially from the educated human resources available in this region while also promoting the welfare of previously marginalized women by providing them with a well-equipped and accessible office. In parallel, this practice fulfilled the commercial objectives of AlphaCorp by providing more options for recruitment. The pick-up and drop-off service encouraged families to allow their daughters to work at AlphaCorp, and the practice satisfied the social objective of employing marginalized people in the remote area. Moreover, the pick-up and drop-off service reduced the likelihood of absenteeism due to poor public transport and/or adverse weather conditions.

The final mechanism, embedding, extends prior work in impact sourcing by showing how management practices of GITO organizations can inculcate change in the institutional logics for instance "raising the glass ceiling" for women employees. The mechanisms are interdependent and mutually enforcing. For example, the embedding mechanism explains the changes to community and family logics that enabled AlphaCorp's community acceptance. The synchronization mechanism also played a part in this process by mirroring the local norms and values in practices.

Some mechanisms complement each other and respond to different institutional logics. For example, AlphaCorp provided recreational activities to encourage employees to perform better and improve their professional skills. The company allowed family members to accompany employees on trips, which helped gain families' acceptance, and exemplifies the embedding mechanism in action. Allowing a family member to attend recreational trips with staff members not only aligned to the family institutional logics by embedding trust but also influenced the profession institutional logics of improved work quality (the bridging mechanism in 
action). Ultimately, this was the targeted outcome for why AlphaCorp provided a recreational activity to employees who had worked hard. Without this intervention, some female employees may have been less motivated to win the reward, which may have limited the professional skills they gained.

This research also contributes to the study of institutional logics particularly, to the concepts of multiplicity of institutional logics (Besharov \& Smith, 2014). The case analysis demonstrates that institutional logics are not mutually exclusive and that the institutional logics may influence other institutional logics in the inter-institutional system. For example, profession institutional logics that associated teaching with women-friendly professional attributes are intertwined with family and community logics. These findings concur with the existing studies of institutional logics (Thornton \& Ocasio, 2008; Thornton et al., 2012).

This study and the process framework that we depict have practical relevance to the management strategies that GITO employs when seeking to respond to the institutional challenges that local contexts pose. It can help guide impact-sourcing managers to ensure their management practices align with existing institutional challenges in order to gain social and commercial advantages.

As with any study, this one has limitations. We considered the institutional logics most pertinent in the local context and did not consider the influences across broader institutional orders such as the state, market, and corporation. We thus call for future research to explore the institutionally aligned management practices extending the level of analysis and including other actors, such as government entities, customers, and intermediaries.

Following Walsham's $(1995,2006)$ guidance on making generalizations from interpretive cases, we draw our theoretical development from a combined framework and the illustration of the concepts from the empirical case in order to offer our insights. However, we encourage future work in different contexts that focuses on other marginalities (e.g., age, ethnicity, disabilities, and education) so that we may progress towards building a generalized theory related to the implementation of impact sourcing. Our case study identifies three mechanisms that impact-sourcing organizations and mainstream GITO engaging in impact sourcing work may use to implement institutionally aligned management practices to achieve both social and 
commercial objectives. We presume that future studies will identify more

mechanisms and, thereby, mature the theory-building process in this domain.

\section{REFERENCES}

Accenture. (2012). Exploring the value proposition for impact sourcing-the buyer's perspective. Retrieved from https://www.accenture.com/us-en/insight-exploring-value-proposition-impactsourcing.aspx

Accenture. (2013). Recruitment, training, and impact measurement; a recommended approach for impact sourcing. Retrieved from https://www.rockefellerfoundation.org/report/recruitmenttraining-and-impact-measurement-a-recommended-approach-for-impact-sourcing/

Ali, F. (2013). A multi-level perspective on equal employment opportunity for women in Pakistan. Equality, Diversity and Inclusion: An International Journal, 32(3), 289-309.

Astrid Siegmann, K., Nazima;, S., Aslam, M., Sikandar Baloch, I., \& Asghar, S. (2010). Gender digital divide in rural pakistan: To measure and to bridge it; revised final technical report, November 2007 - April 2010. Retrieved from https://idl-bnc-idrc.dspacedirect.org/handle/10625/50907

A.T. Kearney. (2016). 2016 a.T. Kearney global services location index ${ }^{\mathrm{TM}}$. Retrieved from https://www.atkearney.com/digital-transformation/article?/a/2016-global-services-locationindex-

Avasant. (2012). Incentives \& opportunities for scaling the "impact sourcing" sector. Retrieved from http://www.avasant.com/research/impactsourcing

Avgerou, C. (2013). Social mechanisms for causal explanation in social theory based IS research. Journal of the Association for Information Systems, 14(8), 399-419.

Babin, R., Nicholoson, B., \& Young, M. (2016). Impact sourcing: Aboriginal case study In B. Nicholson, R. Babin, \& M. Lacity (Eds.), Socially responsible outsourcing: Global sourcing with social impact. (Technology, Work and Globalization). Basingstoke, Hampshire, UK: Palgrave Macmillan

Barley, S. R. (2008). Coalface institutionalism. In R. Greenwood, C. Oliver, T. B. Lawrence, \& R. E. Meyer (Eds.), The Sage handbook of organizational institutionalism (2nd ed., pp. 491-518). Thousand Oaks, CA: Sage.

Bazeley, P., \& Jackson, K. (2013). Qualitative data analysis with Nvivo. Thousand Oaks, CA: Sage.

Besharov, M. L., \& Smith, W. K. (2014). Multiple institutional logics in organizations: Explaining their varied nature and implications. Academy of Management Review, 39(3), 364-381.

Brint, S. (2001). Gemeinschaft revisited: A critique and reconstruction of the community concept. Sociological Theory, 19(1), 1-23.

Carmel, E., Lacity, M. C., \& Doty, A. (2014). The impact of impact sourcing: Framing a research agenda. In R. Hirschheim, A. Heinzl, \& J. Dibbern (Eds.), Information systems outsourcing: Towards sustainable business value (4th ed., pp. 397-429). Heidelberg, Berlin: Springer

ERRA. (2007). BAGH district profile. Retrieved from www.erra.pk/Reports/KMC/BaghProfile200907.pdf

Falck, O., \& Heblich, S. (2007). Corporate social responsibility: Doing well by doing good. Business Horizons, 50(3), 247-254.

Ferdoos, A. (2005). Social status of rural and urban working women in Pakistan-a comparative study (doctoral thesis). University of Osnabrück, Mülheim, Germany.

Friedland, R., \& Alford, R. R. (1991). Bringing society back in: Symbols, practices and institutional contradictions The new institutionalism in organizational analysis (1st ed., pp. 232-263). Chicago, IL: The University of Chicago Press.

Greenwood, R., Díaz, A. M., Li, S. X., \& Lorente, J. C. (2010). The multiplicity of institutional logics and the heterogeneity of organizational responses. Organization Science, 21(2), 521-539.

Hedström, P., \& Swedberg, R. (1998). Social mechanisms: An analytical approach to social theory. Cambridge, UK: Cambridge University Press.

Heeks, R., \& Arun, S. (2010). Social outsourcing as a development tool: The impact of outsourcing IT services to women's social enterprises in Kerala. Journal of International Development, 22(4), 441-454.

Henfridsson, O., \& Yoo, Y. (2014). The liminality of trajectory shifts in institutional entrepreneurship. Organization Science, 25(3), 932-950.

Howcroft, D., \& Richardson, H. (2008). Gender matters in the global outsourcing of service work. New Technology, Work and Employment, 23(12), 44-60. 
Ismail, S. A., Heeks, R., Nicholson, B., \& Aman, A. (2017). Analyzing conflict and its management within ICT4D partnerships: An institutional logics perspective. Information Technology for Development, 1-23.

Jarzabkowski, P., \& Spee, A. P. (2009). Strategy as practice: A review and future directions for the field. International Journal of Management Reviews, 11(1), 69-95.

Khan, S., Lacity, M., \& Carmel, E. (2018). Entrepreneurial impact sourcing: A conceptual framework of social and commercial institutional logics. Information Systems Journal, 28(3), 538-562. doi:10.1111/isj.12134

King, N. (2012). Doing template analysis. In G. Symon \& C. Cassell (Eds.), Qualitative organizational research: Core methods and current challenges (pp. 426-450). London, UK: Sage Publications Ltd.

Klein, H. K., \& Myers, M. D. (1999). A set of principles for conducting and evaluating interpretive field studies in information systems. MIS Quarterly, 23 (1), 67-93.

Lacity, M., Rottman, J., \& Carmel, E. (2012). Emerging ITO and BPO markets: Rural outsourcing and impact sourcing. (IEEE Ready Notes Series). US: IEEE Computer Society.

Lacity, M., Rottman, J., \& Khan, S. (2010). Field of dreams: Building IT capabilities in rural America. Strategic Outsourcing: An International Journal, 3(3), 169-191.

Lacity, M., Rottman, J. W., \& Carmel, E. (2014). Impact sourcing: Employing prison inmates to perform digitally-enabled business services. Communications of the Association for Information Systems, 34, 914-932.

Madon, S., \& Ranjini, C. R. (2018). Impact sourcing in india: Trends and implications. Information Systems Journal. doi:10.1111/isj.12220

Madon, S., \& Sharanappa, S. (2013). Social IT outsourcing and development: Theorising the linkage. Information Systems Journal, 23(5), 381-399.

Malik, F., Nicholson, B., \& Heeks, R. (2017). Understanding the development implications of online outsourcingThe 14th International Conference on Social Implications of Computers in Developing Countries (IFIP WG 9.4)IFIP Advances in Information and Communication Technology Series (Vol. 504). Yogyakarta, Indonesia: Springer Link.

Malik, F., Nicholson, B., \& Morgan, S. (2016). Assessing the social development potential of impact sourcing. In M. Lacity, B. Nicholson, \& R. Babin (Eds.), Socially responsible outsourcing: Global sourcing with global impact. United Kingdom: Palgrave Macmillan.

Miller, D., Breton-Miller, L., \& Lester, R. H. (2011). Family and lone founder ownership and strategic behaviour: Social context, identity, and institutional logics. Journal of Management Studies, 48(1), 1-25.

Monitor. (2011). Job creation through building the field of impact sourcing. Retrieved from http://www.rockefellerfoundation.org/media/download/c2cbb5d3-500c-4ced-8387a7469b567b98

Mughal, M. A. Z. (2014). Time, space and social change in rural Pakistan: An ethnographic study of Jhokwala Village, Lodhran District (doctoral thesis). Durham University, UK. Retrieved from http://etheses.dur.ac.uk/9492/

Myers, M. D., \& Newman, M. (2007). The qualitative interview in IS research: Examining the craft. Information and Organization, 17(1), 2-26.

Nicholson, B. (2015). Global sourcing and development: New drivers, models and impacts. Information Systmes Journal, 25(1), 61-63.

Planning and Development Department Muzaffarabad. (2013). Azad Jammu \& Kashmir, at a glance. Retrieved from http://www.financeajk.gok.pk/webdata/PDF\%20for\%20Web/AJK\%20at\%20a\%20glance\%202013\%20final.pdf

Porter, M., E., \& Kramer, M., R. (2006). Strategy \& society: The link between competitive advantage and corporate social responsibility. Harvard Business Review, 84(12), 78-92.

Porter, M., E., \& Kramer, M., R. (2011). Creating shared value. Harvard Business Review, 89(12), 6277.

Reay, T., \& Hinings, C. R. (2005). The recomposition of an organizational field: Health care in Alberta. Organization Studies, 26(3), 351-384.

Reay, T., \& Jones, C. (2016). Qualitatively capturing institutional logics. Strategic Organization, 14(4), 441-454.

Reckwitz, A. (2002). Toward a theory of social practices: A development in culturalist theorizing. European Journal of Social Theory, 5(2), 243-263.

Rehman, S., \& Roomi, M. A. (2012). Gender and work-life balance: A phenomenological study of women entrepreneurs in Pakistan. Journal of Small Business and Enterprise Development, 19(2), 209-228. 
Robertson, R. (2012). Globalisation or glocalisation? Journal of International Communication, 18(2), 191-208.

Sandeep, M., \& Ravishankar, M. (2018). Sociocultural transitions and developmental impacts in the digital economy of impact sourcing. Information Systems Journal, 28(3), 563-586.

Sandeep, M., \& Ravishankar, M. (2015a). Impact sourcing ventures and local communities: A frame alignment perspective. Information Systems Journal, 26(2), 127-155.

Sandeep, M., \& Ravishankar, M. (2015b). Social innovations in outsourcing: An empirical investigation of impact sourcing companies in India. The Journal of Strategic Information Systems, 24(4), 270-288.

Sandeep, M., Ravishankar, M., \& Hislop, D. (2013). The establishment of social IT sourcing organizations: An impression management perspective. Paper presented at the 34th International Conference on Information Systems, Milan, Italy.

Sathar, Z. A., \& Kazi, S. (2000). Women's autonomy in the context of rural Pakistan. The Pakistan Development Review, 39(2), 89-110.

Schatzki, T. R. (1996). Social practices: A Wittgensteinian approach to human activity and the social. Cambridge, UK: Cambridge University Press.

Schatzki, T. R. (2006). On organizations as they happen. Organization Studies, 27(12), 1863-1873.

Silverman, D. (2006). Interpreting qualitative data: Methods for analyzing talk, text and interaction. Thousand Oaks, CA: Sage.

Smets, M., Jarzabkowski, P., Burke, G. T., \& Spee, P. (2015). Reinsurance trading in Lloyd's of London: Balancing conflicting-yet-complementary logics in practice. Academy of Management Journal, 58(3), 932-970.

Smets, M., Morris, T., \& Greenwood, R. (2012). From practice to field: A multi-level model of practicedriven institutional change. Academy of Management Journal, 55(4), 877-904.

Suddaby, R., Seidl, D., \& Le, J. (2013). Strategy-as-practice meets neoinstitutional theory. Strategic Organization, 11(3), 329-344.

Thornton, P. H., \& Ocasio, W. (2008). Institutional logics. In R. Greenwood, C. Oliver, K. Sahlin, \& R. Suddaby (Eds.), Organizational institutionalism. Thousand Oaks, CA: Sage.

Thornton, P. H., Ocasio, W., \& Lounsbury, M. (2012). The institutional logics perspective: A new approach to culture, structure, and process. Oxford, UK: Oxford University Press.

Trivedi, C., \& Stokols, D. (2011). Social enterprises and corporate enterprises: Fundamental differences and defining features. The Journal of Entrepreneurship, 20(1), 1-32.

Valk, R., \& Srinivasan, V. (2011). Work-family balance of indian women software professionals: A qualitative study. IIMB Management Review, 23(1), 39-50.

Walsham, G. (1995). Interpretive case studies in IS research: Nature and method. European Journal of Information Systems, 4(2), 74-81.

Walsham, G. (2006). Doing interpretive research. European Journal of Information Systems, 15(3), 320-330.

Weiss, A. M. (1994). Challenges for Muslim women in a postmodern world. In A. S. Ahmed \& H. Donnan (Eds.), Islam, globalization and postmodernity (pp. 127-140). New York, NY: Routledge.

William Davidson Institute. (2013). Impact sourcing-assessing the opportunity for building a thriving industry. Retrieved from www.rockefellerfoundation.org/app/uploads/Assessing-theOpportunity-for-Building-a-Thriving-Industry.pdf 